\title{
CORRECTION
}

\section{Correction to: Lessons from the rise and fall of Chinese peer-to-peer lending}

\author{
Chen Ding ${ }^{1,2} \cdot$ Anil S. Kavuri $^{2,3} \cdot$ Alistair Milne $^{2}$
}

Published online: 4 January 2021

(c) Springer Nature Limited 2021

\section{Correction to: Journal of Banking Regulation https://doi.org/10.1057/s41261-020-00132-2}

The article title was incorrect in the original publication of the article. The correct article title should read as given below:

Lessons from the rise and fall of Chinese peer-to-peer lending

The original article has been corrected.
Publisher's Note Springer Nature remains neutral with regard to jurisdictional claims in published maps and institutional affiliations.

The original article can be found online at https://doi.org/10.1057/ s41261-020-00132-2.

\section{Anil S. Kavuri}

A.S.Kavuri@lboro.ac.uk

1 University of Sheffield, Sheffield, UK

2 Loughborough University, Loughborough, UK

3 Centre of Applied Macroeconomic Analysis, Australian National University (ANU), Canberra, Australia 